\title{
Proceeding
}

Supplementary Issue: Rio 2016 Olympic Games First Anniversary Special Edition. Olympic Studies Forum, 4-5 August 2017. Santa Úrsula University. Rio de Janeiro, Brazil

\section{Porto Maravilha: Urban dynamics of a changing tertiary sector after Rio 2016}

\author{
RENATA LATUF DE OLIVEIRA SANCHEZ \\ School of Architecture and Urban Planning, University of São Paulo, Brazil
}

\begin{abstract}
Rio Olympics 2016 triggered a series of urban works to grant Rio its new status as a "global" and "Olympic" city. Among these works, there is the great urban regeneration called "Porto Maravilha" in the harbor area, whose financial injection - despite not directly related to the Games -, and importance in reshaping a strategic and historical central area has turned it into one of the most publicized Olympic legacies. This paper explores the importance of the "tertiary space" in the project's success, by analyzing its transformations in two main areas of the initial interventions: Sacadura Cabral Street, between Mauá Square and Barão de Tefé Avenue; and the Olympic Boulevard. Urban theories regarding formation of centralities (Vargas, 2014a), creation of urban vitality and ambiences (Gehl, 1996), the relation between tertiary space and "urban sustainability" (Salgueiro, 2011), as well as the idea of different times in urban spaces (the slow and the fast) (Cachinho, 2010), are used in order to comprehend relations between users and city. As methods, this paper uses empirical observations from a field trip in May 2017 (counting, mapping, diary writing and photographing (Gehl, 2013), as well as land use maps made in loco by the author. By comparing the above mentioned localities with two other consolidated central areas - the Mercado and Assembleia streets -, this paper emphasizes aspects that determine different profiles of tertiary activities in each region, which reflect in their urban dynamics and the legacy of Porto Maravilha in physical, social and economic terms. Key words: OLYMPIC LEGACY, TERTIARY SPACE, URBANISM, URBAN REGENERATION, RIO 2016.
\end{abstract}

\section{Cite this article as:}

Latuf de Oliveira Sanchez, R. (2018). Porto Maravilha: Urban dynamics of a changing tertiary sector after Rio 2016. Journal of Human Sport and Exercise, 13(1proc), S26-S45. doi:https://doi.org/10.14198/jhse.2018.13.Proc1.04

\footnotetext{
Corresponding author. Faculdade de Arquitetura e Urbanismo, Universidade de São Paulo, Brasil. http://orcid.org/0000-00027094-0175

E-mail: renata_los@hotmail.com Supplementary Issue: Rio 2016 Olympic Games First Anniversary Special Edition. Olympic Studies Forum, 4-5 August 2017. Santa Úrsula University. Rio de Janeiro, Brazil. JOURNAL OF HUMAN SPORT \& EXERCISE ISSN 1988-5202

(c) Faculty of Education. University of Alicante doi:10.14198/jhse.2018.13.Proc1.04
} 


\section{Porto Maravilha: Dinâmicas urbanas do terciário em transformação pós-Rio 2016}

\section{RESUMO}

As Olimpíadas do Rio de Janeiro em 2016 envolveram uma série de obras urbanísticas para remodelar e adaptar a cidade a seu novo status de "cidade global" e "olímpica". Dentre essas obras, destaca-se a grande operação urbana consorciada "Porto Maravilha" (OUCPM), cujo aporte de investimentos, apesar de não diretamente relacionado aos Jogos, e importância na regeneração de uma área estratégica e histórica central garantiu-lhe a alcunha de um dos maiores legados olímpicos. Este artigo explora a importância do setor terciário no sucesso da operação, analisando suas transformações em duas áreas principais da primeira fase de intervenção: a Rua Sacadura Cabral, entre o trecho da Praça Mauá e Avenida Barão de Tefé; e o Boulevard Olímpico. Utilizam-se teorias urbanísticas referentes à formação de centralidades (Vargas, 2014a), geração de ambiências e vitalidade urbana (Gehl, 1996), relação do terciário com a "sustentabilidade urbana" (Salgueiro, 2011); bem como a ideia de espaços de tempos distintos - lento e rápido (Cachinho, 2010), para compreender as relações entre usuário e cidade. Como metodologia, observações empíricas em pesquisa de campo em maio de 2017 (contagem, mapeamento, elaboração de diário e fotografias (Gehl, 2013)), além da elaboração de mapas de uso do solo in loco. Confrontando as regiões escolhidas com outras duas áreas consolidadas centrais (Rua do Mercado e Rua da Assembleia), evidenciam-se aspectos que determinam o perfil distinto das atividades terciárias de cada região, refletindo também no perfil da dinâmica urbana de cada área, determinante para o "legado" que será consolidado em termos físicos, sociais e econômicos. Palavras-chave: LEGADO OLÍMPICO, ESPAÇO TERCIÁRIO, URBANISMO, REGENERAÇÃO URBANA, RIO 2016. 


\section{INTRODUÇÃO}

O Rio de Janeiro, no intuito de se tornar "cidade global" e olímpica, conseguiu concretizar um de seus antigos planos de reestruturação da área portuária, com a revitalização de sua orla e espaços públicos, inaugurada em 2016, juntamente às Olimpíadas e Paralimpíadas do Rio de Janeiro. O projeto, que havia sido discutido desde a década de 1980 (DEL RIO, 2001), nunca havia conseguido o alinhamento necessário entre as esferas governamentais e o impulso para sua concretização, os quais as Olimpíadas trataram de trazer, devido à sua visibilidade e ao aporte de investimentos. Assim, a Operação Urbana Consorciada Porto Maravilha (OUCPM) ${ }^{1}$ foi instituída em 23 de novembro de 2009, através da Lei Complementar 101/2009, um mês após o Rio de Janeiro ser anunciado como sede dos Jogos de 2016, sendo amplamente divulgada como um dos legados do megaevento. Parte do Plano de Políticas Públicas², a operação estabelece uma série de transformações em uma área de cinco milhões de metros quadrados vulnerável e degradada do centro do Rio, por anos negligenciada pelo poder público e olhada com desinteresse pelo mercado imobiliário. Berço do Rio de Janeiro, compreendendo os bairros de Santo Cristo, Gamboa e Saúde, além de partes de bairros vizinhos e do centro, passou por forte processo de desindustrialização e emigração, possuindo atualmente cerca de 22 mil habitantes. A OUCPM pretende aumentar este número para cem mil em 2020, estimulando novos empreendimentos residenciais e de uso misto na região. 0 contrato, assinado por uma PPP entre a Concessionária Porto Novo (OAS, Carioca Engenharia e Odebrecht) e a Companhia de Desenvolvimento Urbano da Região do Porto (CDURP), empresa de economia mista controlada pela Prefeitura, vigorará até 2026. A CDURP foi criada para coordenar o processo de implantação da operação urbana e sua sede construída na Rua Sacadura Cabral, uma das primeiras áreas a serem remodeladas, próxima à Praça Mauá. Dividida em duas fases de desenvolvimento, a OUCPM empreendeu primeiramente a requalificação da Praça Mauá (finalizada com a abertura do Museu do Amanhã, de Santiago Calatrava); a conclusão de infraestrutura (iluminação, calçadas, drenagem, etc.) em algumas ruas e avenidas importantes do entorno, como a R. Sacadura Cabral e a Av. Rodrigues Alves, que margeia os armazéns portuários; a demolição do elevado da Perimetral e implantação da via Binário do Porto, que garantiram integração visual da orla com a região.

Compreendendo a venda dos certificados de potencial adicional construtivo (CEPACs) como principal fonte de recurso, a OUCPM busca atrair o poder privado através da concessão de maiores coeficientes de aproveitamento (permitindo maximizar seus lucros), ao mesmo tempo em que incentiva a criação de skylines cada vez mais marcantes na paisagem urbana. Vendidos em lote único à Caixa Econômica Federal, com recursos do FGTS, os CEPACs permitirão a construção de até $150 \mathrm{~m}$ ou 50 pavimentos ao longo da Av. Francisco Bicalho, uma das novas centralidades propostas e, próximo à Praça Mauá e ao Boulevard Olímpico, de até $90 \mathrm{~m}$ ou 30 pavimentos em determinadas quadras, o que poderá mudar bastante o cenário da região se a Caixa conseguir vender os títulos a potenciais investidores. No entorno de morros e áreas tombadas não se aplicam CEPACs, garantindo-se a ambiência dos mesmos, como na R. Sacadura Cabral, com gabarito máximo de dois pavimentos. Os recursos dos CEPACs financiaram obras de infraestrutura em toda a área (novas redes de esgotamento sanitário, abastecimento de água, energia elétrica, telefonia, gás

\footnotetext{
${ }^{1}$ As Operações Urbanas Consorciadas (OUCs) no Brasil foram instituídas pelo Estatuto da Cidade em 2001 e caracterizam-se por intervenções coordenadas pelo poder público municipal, com participação do poder privado junto a moradores, proprietários e usuários permanentes, no intuito de "alcançar em uma área transformações urbanísticas estruturais, melhorias sociais e a valorização ambiental" (BRASIL, 2001, art. 32, $\S 1^{\circ}$ ). Entretanto, devido ao desalinhamento de interesses entre os diversos agentes, questionam-se os benefícios a todos os envolvidos (FERREIRA, 2004; NOBRE; BASSANI, 2015).

20 Plano de Políticas Públicas era uma das três esferas do orçamento dos Jogos 2016 e caracterizava-se por investimentos em obras não relacionadas aos Jogos, mas aceleradas em virtude dos mesmos, como o caso da OUC Porto Maravilha.
} 
encanado, novo mobiliário urbano), além da conclusão de obras viárias como a via Binário do Porto e o túnel Rio 450.

Além do gabarito, outros parâmetros urbanísticos, como vagas de estacionamento, também foram alterados. Novos empreendimentos comerciais deverão ter uma vaga para cada $50 \mathrm{~m}^{2}$ (antes, uma a cada $30 \mathrm{~m}^{2} \mathrm{em}$ salas comerciais e 1 a cada $25 \mathrm{~m}^{2}$ para lojas) e empreendimentos residenciais, uma vaga para cada unidade (Porto Maravilha, [201-?], p.254). Todas essas transformações afetam diretamente na realização de novos empreendimentos imobiliários e na dinâmica do setor terciário existente e futuro da região. 0 alargamento de calçadas, por exemplo, retira vagas de estacionamento na frente de comércios, interferindo na logística com os consumidores. A transposição ou extinção de linhas de ônibus também impacta nos fluxos que uma determinada rua passa ou deixa de receber e, portanto, em alguns comércios locais. Novos empreendimentos de torres empresariais, se desejam que seus trabalhadores incorporem o transporte público e as ciclovias como meio principal de acesso (uma vez que terão menos vagas de estacionamentos), deverão prever espaços adequados de vestiários e estacionamentos de bicicletas, por exemplo. Por sua vez, a requalificação da Praça Mauá e sua destinação como polo turístico e símbolo da regeneração da área afeta diretamente em seu entorno, funcionando como a grande "âncora" da OUC, ainda que a passos lentos no momento de recessão econômica brasileiro.

O presente artigo pretende explorar a importância do setor terciário para o sucesso da OUC Porto Maravilha. Tendo em vista a extensão e pouca maturação da operação, uma vez que a mesma vigorará por 15 anos, escolheram-se duas áreas principais da primeira fase de intervenção para análise, a saber: a Rua Sacadura Cabral, entre o trecho da Praça Mauá e Avenida Barão de Tefé; e o Boulevard Olímpico, na Avenida Rodrigues Alves, desde a Praça XV até o novo Aquário Municipal (Figura 1). Analisam-se tais áreas sob: 0 discurso da formação de nova centralidade de negócios, destacando as ações para atingir esse propósito; a questão do desenho urbano como gerador de ambiências e vitalidade urbana (Gehl, 1996, 2013); a variedade de usos e usuários, procurando avaliar a "sustentabilidade urbana" conceituada por Teresa Salgueiro (2011); bem como a ideia de espaços de tempos distintos na área de intervenção - o tempo lento e o tempo rápido -, como descreve Herculano Cachinho (2010). Que características definem esse (novo) "lugar"? Quais novos parâmetros legais contribuem para uma definição do local como polo de negócios ou nova centralidade? Como o tecido e dinâmica urbanos existentes ajudam ou limitam esse objetivo?

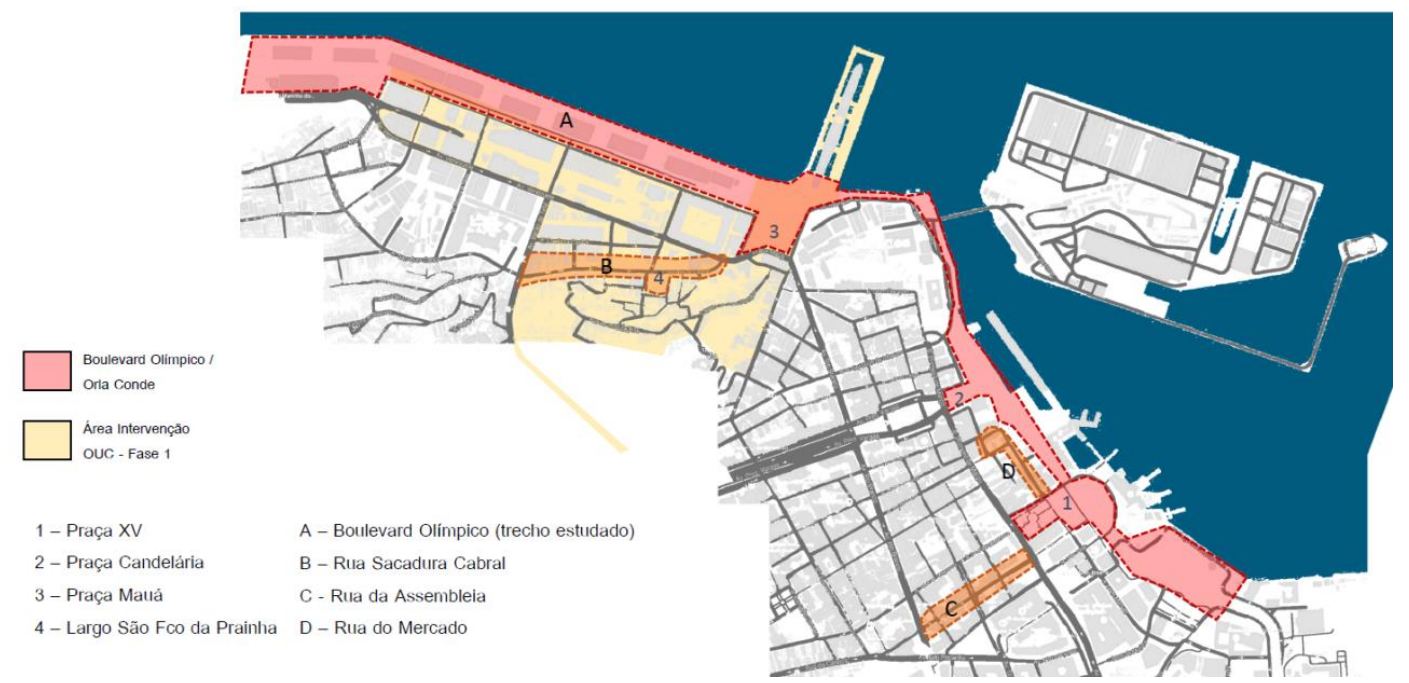

Figura 1. Mapa das áreas estudadas, com a marcação de algumas das principais praças que fazem parte do percurso 
Para tanto, além dos conceitos teóricos, utilizam-se registros de observação durante pesquisa de campo realizada em maio de 2017, que são confrontados em determinados momentos com outras duas visitas realizadas à cidade em 2016, em agosto e outubro, durante e após o megaevento. Métodos empíricos de observação de espaços públicos como contagem, mapeamento, elaboração de diário e fotografias (GEHL, 2013) ajudaram a compreender as relações entre pessoas e espaço físico, usuário e cidade. Além disso, mapas de uso do solo elaborados in loco, juntamente a uma pesquisa qualitativa com alguns comerciantes da região, revelaram características do local não visíveis "a olho nu" ou ao mero turista. O conjunto de dados coletados associado aos desenhos ajuda a começar a avaliar processos de transformação das áreas selecionadas em termos físicos, sociais e econômicos, como a "gentrificação".

Tendo em mente que toda intervenção acarreta transformações a curto, médio e longo prazo, não cabe a esse artigo realizar afirmações definitivas sobre o "legado" desses espaços pela OUC Porto Maravilha (ou mesmo pelas Olimpíadas, uma vez que foram catalisador para a operação e não motivo primário), mas sim avaliar 0 que até 0 momento é exposto e usufruído e como essas áreas têm se integrado à cidade consolidada até o momento. A título de comparação, realizou-se pesquisa de usos do solo também em duas partes do centro consolidado do Rio de Janeiro: a Rua da Assembleia (eixo de conexão entre o Metrô Carioca e a Praça XV e estação de barcas) e a Rua do Mercado (rua praticamente para pedestres próxima à nova orla e à Praça XV). Destacam-se essas duas ruas por suas características distintas e inserção urbana, sendo a primeira um polo importante de negócios e instituições públicas e a segunda uma área recentemente integrada à orla renovada e caminho turístico, visto sua arquitetura histórica e proximidade a importantes equipamentos culturais (como o Centro Cultural Banco do Brasil), passando atualmente por transformações em seu caráter. Ao confrontar as características dessas áreas centrais consolidadas com aquelas estudadas dentro da OUC, evidenciam-se alguns aspectos que determinam o perfil distinto das atividades terciárias de cada região, refletindo também no perfil da dinâmica urbana de cada área.

\section{A IMPORTÂNCIA DO TERCIÁRIO NA CRIAÇÃO DE LUGARES VIBRANTES E SUSTENTÁVEIS}

Na transformação da cidade em produto - e produto global -, valoriza-se a criação do "lugar". Ao mesmo tempo em que a competição entre as cidades levou a uma homogeneização do espaço urbano, com as mesmas empresas, redes varejistas, marcas, formatos de arquitetura ou urbanismo e suas assinaturas, há uma busca constante pela diferenciação, exaltando as características que só uma cidade ou outra pode fornecer. Neste sentido, destacam-se os conceitos de "localização" e "lugarização"; o primeiro determinando relações com o entorno, o segundo estabelecendo parâmetros que remetem ao próprio local, como história, tradição e cultura (VARGAS, 2014a). No caso da OUCPM, ambos conceitos são evidentes. Sua localização, irreproduzível pelas belezas naturais do entorno, da Baía de Guanabara, é complementada por séculos de história, obras e intervenções urbanas (inclusive as da OUC), resultando em acessibilidade, tecido urbano consolidado, caráter único e presença de importantes instituições, órgãos e equipamentos culturais, constituintes de polos geradores de fluxos. Tais aspectos aumentam as expectativas com a operação urbana, ao possibilitar "reabilitar" uma localização estratégica, adensando-a com novos postos de trabalho, moradia, lazer, comércio e serviços. Ao mesmo tempo, a historicidade da região aproxima a criação de uma nova centralidade aos discursos de "lugarização". Manifestações culturais populares como o samba, o angu e o carnaval tiveram ali suas origens e fazem parte da "formação" do caráter do local, transformando-o em "lugar", aspecto a ser incorporado nos projetos arquitetônicos e urbanísticos.

A regeneração de áreas degradadas e a consequente atração de capital para o local acarretará sempre em uma valorização, tendo em vista a própria ideia de "regenerar". A apropriação da localização atraente do Porto Maravilha (e de sua acessibilidade) e das obras de infraestrutura empreendidas em decorrência da 
OUC inevitavelmente geram especulação imobiliária, já observada pelo aumento de preços em alugueis e vendas de imóveis na região, muitos, entretanto, ainda desocupados. No entanto, tal aumento decorre não somente de especulação, mas da aplicação de capital na área gerando renda diferencial. É evidente que a transformação da orla - denominada Boulevard Olímpico ou Orla Conde - proporcionada pela substituição do elevado da Perimetral por um túnel criou uma ambiência urbana muito mais agradável a diferentes grupos de usuários e atraente a novos investimentos privados do que antes, possibilitando dinamizar a região através da diversificação de usos comerciais e de serviços. As transformações urbanas empreendidas consolidam uma nova função urbana, decorrente de sua nova forma ${ }^{3}$, compatível tanto com a visão de tornar o Rio de Janeiro uma cidade global e competitiva, quanto com a necessidade de recuperar áreas centrais degradadas, devolver o patrimônio histórico à sociedade (também pelo turismo) e promover urbanidades mais interessantes, uma tendência contemporânea mundial.

Neste processo, não se pode negligenciar a importância do varejo, uma vez que sua implantação implicará não apenas no lote em que se insere, mas em todo seu entorno e contexto, valorizando determinados pontos do território até então subestimados. A atração de públicos diferentes para a área impõe desafios ao comércio existente e futuro, que deverá se adaptar a uma crescente variedade de gostos, estilos de vida e poder aquisitivo. A convivência do antigo com o novo, apesar de um desafio, é benéfica ao dinamismo e sustentabilidade da região, na medida em que permite a coexistência de diferentes grupos sociais, atividades e usos. ${ }^{4} \mathrm{~A}$ preservação de certas tradições, junto à modernização de algumas estruturas, contribui para a manutenção do "lugar" e reforço da "localização".

Em termos da sustentabilidade e resiliência do lugar (a capacidade de se adaptar às mudanças e se manter atraente e dinâmico), destaca-se a importância ainda do desenho e planejamento urbanos, que deverão permitir alterações nos usos e atividades ao longo do tempo, sem que o lugar perca sua identidade. Planos extremamente "reguladores" e estanques são contra produtivos para a dinâmica urbana, em constante mudança junto à sociedade. A sustentabilidade urbana vem sendo amplamente discutida por teóricos e urbanistas, que retomam alguns conceitos exaltados na década de 1960 contra o planejamento moderno e o funcionalismo das cidades para automóveis. $O$ arquiteto e urbanista dinamarquês Jan Gehl, cujo lema "cidades para pessoas" difunde há mais de cinco décadas, exalta os benefícios da escala humana, bairros de uso misto (comércio, universidades, residências, etc.), pedestrianização de ruas em centros urbanos, fachadas mais estreitas (para aumentar as atividades em menor raio de distância) e ativas (com detalhes para o olhar do pedestre, reentrâncias ou elementos que permitam sentar, ficar de pé, reunir-se, etc., além de lojas e cafés), valorização de praças, parques e calçadas para tornar espaços urbanos mais convidativos e agradáveis ao caminhar e à permanência de pessoas (GEHL; GEMZØE, 1996, p.32). Gehl retoma a questão dos "olhos da rua" exaltada por Jane Jacobs: o uso misto leva à diversidade de pessoas frequentando um mesmo espaço em diferentes períodos do dia, o que aumentaria a sensação de segurança.

Diversos tipos de atividades, classificadas por Gehl entre "necessárias" (como caminhar de um lugar a outro) ou "opcionais" (relacionadas a espaços aprazíveis, de recreação e lazer), dependem do desenho urbano e das relações que serão estabelecidas com os passantes. Sendo o consumo uma dessas atividades, cabe

\footnotetext{
3Lefebvre (1970, p.23) aponta para a nova arquitetura e forma urbana assumidas pela cidade europeia ocidental no séc. XIV ao adquirir a função da "troca comercial"; Manuel Castells define e relaciona posteriormente "função urbana" e "forma urbana", essa última a "expressão simbólica do significado de urbano e da superposição histórica de significados urbanos (e suas formas), sempre determinados por um processo conflituoso entre atores históricos" (Castells, 1983, p.25, tradução nossa).

4 Tal constatação também é parte das conclusões de um estudo realizado em 2016 pelo National Trust for Historic Preservation (NHTC, 2016), que analisou o impacto do tecido urbano antigo na qualidade e vitalidade urbana em edifícios e bairros de cinquenta cidades americanas. Exaltam-se os benefícios dos pequenos comércios para a economia local, por exemplo.
} 
ressaltar a divisão do mesmo em duas categorias semelhantes, conforme classifica Vargas (2014b): as compras necessárias/obrigatórias e as compras hedônicas, que terão forte influência do espaço em que se situam e do projeto arquitetônico. Relacionando essas questões ainda com a ideia discutida por Cachinho (2010) sobre espaços de tempo rápido e tempo lento, tem-se uma diferenciação notável entre espaços de trabalho/fluxos e espaços de lazer/permanência, cujas características também dependerão do desenho urbano e serão apropriadas pelo setor terciário de distintas maneiras, no intuito de promover um ou outro "tempo". A arquitetura de restaurantes e lojas voltados ao consumo hedônico, por exemplo, refletirá o tempo lento; já a daqueles voltados à necessidade cotidiana, provavelmente não favorecerá a permanência e deleite do usuário. A coexistência de espaços de "tempo lento" e de "tempo rápido" é benéfica à qualidade de vida urbana e deve ser procurada em projetos de regeneração urbana como o Porto Maravilha.

As atividades comerciais possuem, cada vez mais, papel fundamental na manutenção de fluxos e dinamismo em áreas residenciais ou empresariais. Para Teresa Salgueiro (2011), o varejo é um dos pilares da "sustentabilidade urbana", atrelada à resiliência de áreas comerciais e associada à "preservação de sistemas de varejo estabelecidos em uma grande variedade de instalações e ambientes de consumo" (SALGUEIRO, 2011, p.20), que devem atender diferentes grupos de consumidores (classe social, perfil, desejos, etc.). Para ela, uma comunidade não pode ser sustentável se não for capaz de adaptar-se a mudanças e gerenciar riscos. A superação das vulnerabilidades deve ser feita conjuntamente entre tomadores de decisão, especialistas e "habitantes-usuários-consumidores" (SALGUEIRO, 2011, p.40, tradução nossa), evidenciando a importância de todos os agentes.

A transformação da área portuária em polo de lazer e cultura alinha-se às expectativas de gerar consumo no local, uma das condições primordiais para que a área se mantenha dinâmica. Sendo o turismo uma forma extrema de lazer e, visto sua intrínseca relação com o consumo, um tipo de "consumo de lazer", pode ser considerado uma atividade social e uma experiência (TIMOTHY, 2005). Megaeventos estão intimamente relacionados com tais conceitos. Durante as Olimpíadas de 2016, conseguiu-se atrair um grande fluxo de turistas-consumidores à recém-renovada área portuária, impossível sob outras circunstâncias, o que ajudou na divulgação das intervenções da OUC, inclusive nas redes sociais. Estar presente na cidade durante os Jogos e desfrutar das atividades temporárias oferecidas (além das competições esportivas) configurava uma "experiência", intrinsecamente relacionada ao turismo e ao consumo, especialmente o consumo do lugar. A experiência urbana olímpica difere muito, no entanto, daquela cotidiana. Sendo assim, a longo prazo, não se pode subestimar o papel do setor terciário para garantir espaços dinâmicos e diversificados. Entretanto, alguns fatores condicionarão o surgimento e o sucesso de novas atividades de comércio e serviços na área, como localização, preço, propaganda, design físico, atendimento (TIMOTHY, 2005), além de aspectos relacionados ao "ponto comercial", como acessibilidade, atração da loja física, uso do solo do entorno e reputação (NELSON, 1958, apud VARGAS, 2001, p.62).

As análises de questões pontuais das ruas escolhidas neste artigo, a seguir, visam exemplificar os processos de transformação da área portuária decorrentes da OUC Porto Maravilha, com foco nos espaços de comércio e serviços, utilizando para isso as discussões antes expostas a respeito de sua importância para a sustentabilidade urbana e a formação de lugares vivos e dinâmicos.

\section{ESPAÇO TERCIÁRIO NO PORTO MARAVILHA}

\section{Boulevard Olímpico: Eixo Cultural, Varejo e Serviços}

A abertura do Boulevard trouxe a oportunidade de visualizar novamente locais importantes da história do Rio de Janeiro situados na região central, outrora escondidos pelo viaduto da Perimetral, como a Igreja da 
Candelária e o Mosteiro de São Bento, na Praça Mauá. Ao reintegrar orla e cidade, o novo percurso reconectou o tecido urbano consolidado com um dos maiores ativos da cidade: as belezas "naturais" da baía. Durante os Jogos Olímpicos, a área recebeu milhares de turistas e funcionou como ponto de encontro para assistir às competições através dos "live sites". Funcionaram ainda uma série de atividades temporárias ao longo do Boulevard patrocinadas por grandes empresas, como o Balão da Skol que proporcionava vistas espetaculares do centro do Rio e da Baía de Guanabara e o BungeeJump da Nissan, vinculado ao lançamento de um dos automóveis da marca, bem como nos armazéns portuários, como a Casa da NBA, da Coca Cola, a Casa Brasil e um extenso percurso de arte de rua ${ }^{5}$, que ajudaram a construir uma nova identidade ao local, ainda que de forma temporária. Uma vez findados os Jogos, a área ficou praticamente vazia, a não ser pelo fluxo esporádico de turistas e dos trabalhadores da região. A área da Praça Mauá é, sem dúvida, o trecho mais movimentado e tornou-se o grande símbolo da OUC, devido aos dois museus recém instalados na área, um deles com apelos de "starchitecture" e ambiência cenográfica (o que não significa ser um projeto ruim, pelo contrário), além do famoso Mural das Etnias, próximo ao terminal portuário de passageiros.

Em outubro de 2016 e maio de 2017 já se observava certo grau especulativo nas vendas e alugueis de imóveis da região, especialmente no trecho entre a Praça Mauá e o Aquário, onde viam-se diversas placas de "aluga-se" ou "vende-se", especialmente para eventos.

Também em maio de 2017, observou-se uma outra identidade e dinâmica no local, uma vez que os usos temporários - e boa parte das imagens - característicos do período do megaevento se foram. No trecho da Avenida Rodrigues Alves entre a Praça Mauá e o Aquário (Figura 2), havia uma única loja aberta, inaugurada pouco antes dos Jogos de 2016, em um casarão reformado. A loja de roupas carioca "Zibba", localizada no térreo, possui vitrine pequena e letreiros modestos. Vendendo roupas e acessórios femininos para um público de alto padrão (preços em torno de $R \$ 300,00$, mas com peças acima de $R \$ 800,00$ ), com estilo moderno e jovem, atrai um público específico, que possivelmente já a conhecia por suas outras lojas na Barra da Tijuca, Leblon e Niterói. ${ }^{6}$ A fábrica já se localizava na parte de trás do casarão. ${ }^{7}$ No pavimento superior, funciona a "San Chef", marca criada em 1994 especializada em uniformes de alto padrão para gastronomia (chefs, somelliers, barmen, etc.), destacando-se por seu corte, modelagem e tecidos diferenciados. Desde 2005, passou a localizar-se no atual endereço, combinando em um espaço de $500 \mathrm{~m}^{2}$ produção, estoque, showroom, vendas, design e administração. ${ }^{8}$ Além dos uniformes diferenciados, a marca possui linha para ser usada fora da cozinha com apelo ecológico, como aventais de fibra $100 \%$ reciclada e "ecobags", além de turbantes, lenços, "saiões" e jaquetas jeans "para fazer a feira com muito estilo" (RODRIGUES, 2016). Dentre seus clientes, figuram, por exemplo, programas de televisão da Rede Globo, GNT e Record, além de hotéis de redes internacionais como Sofitel, Sheraton e Marriot.

"llhadas" por estacionamentos e armazéns fechados em boa parte do ano, a princípio pode-se questionar a localização das lojas, uma vez que não se inserem em um ambiente dinâmico ou atraente aos consumidores. No entanto, as duas apresentam alguns pontos favoráveis em comum: a relação entre loja e fábrica no mesmo imóvel e a definição clara do público-alvo. Nenhuma das lojas é voltada às compras por impulso,

\footnotetext{
${ }^{5}$ Destacam-se o roteiro \#InstawalkRio, comissionado pelo Instagram com seis trabalhos criados pelos artistas ACME, Luiz Zerbini, Raul Mourão, Rita Wainer e Vik Muniz, que encorajava visitantes a postarem suas fotos nas redes sociais usando a hashtag e 0 Mural das Etnias, do artista Kobra, na época o mais extenso e um dos mais fotografados do mundo.

${ }^{6}$ A estilista da marca, Alice Tapajós, é bastante conhecida no cenário da alta moda carioca desde a década de 1980, por grife que levava seu nome. Assumiu a Zibba em 2010, que inaugurou a primeira loja no Shopping Leblon.

7 Informação dada pela vendedora da loja, em visita em 12/05/2017.

${ }^{8}$ De acordo com website da marca. Ver: http://www.sanchef.com.br/site/san-chef/espacol
} 
que necessitam de grandes letreiros e ambientes consolidados varejistas. No caso da San Chef, trata-se de um comércio especializado e diferenciado, que atrairá seus clientes independentemente da localização pela qualidade do produto e serviços ofertados. Já a Zibba, trata-se de uma marca consolidada no cenário da moda carioca, com unidades em bairros de alta classe, conhecida por um público determinado que poderá visitá-la pela relação já pré-estabelecida com os produtos. No entanto, a abertura recente dessa última no local (2016), após a revitalização da área, apesar da relação com a produção das roupas, parece motivarse na especulação de transformação da região em polo turístico e de consumo, o que ainda está para acontecer, uma vez que novos empreendimentos de negócios (como a futura torre da L'Oréal na rua de trás) entrem em funcionamento e ofereçam um novo mercado consumidor na área, que passará a conhecer a loja também pelo hábito de frequentar a região.

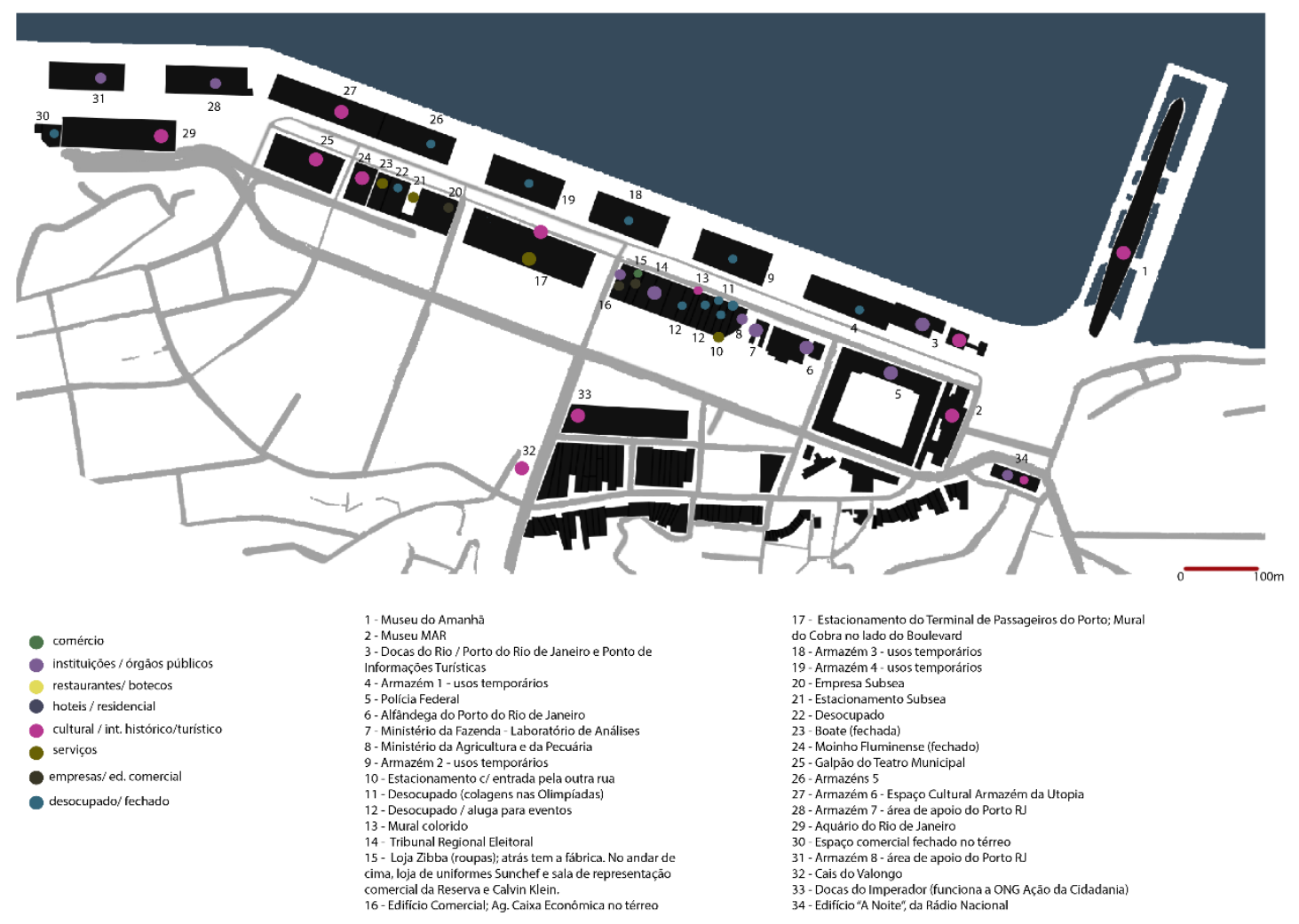

Figura 2. Mapa de uso do solo elaborado em maio de 2017 para o trecho do Boulevard Olímpico entre a Praça Mauá e o Aquário. (Renata Sanchez, 2017)

Se avaliarmos as referidas lojas sob os requisitos apontados por Timothy e Nelson, tem-se uma boa localização, acessível (automóvel particular - estacionamentos -, transporte público -metrô/ônibus/VLT -, a pé - boas calçadas) e próxima ao novo polo de turismo cultural; proximidade à fábrica que produz suas roupas; preço médio-alto (compatível com trabalhadores da região, mas não com os moradores); pouca propaganda (não direcionada à compra por impulso); design moderno em edifício restaurado e, portanto, atraente ao passante; bom atendimento. A proximidade ao público alvo é questionável, porém não é fator determinante para o sucesso, principalmente para a San Chef, como relatado anteriormente. No caso da Zibba, consumidores potenciais de edifícios corporativos e instituições da região talvez não sejam o alvo da marca, cuja unidade provavelmente é pautada em uma especulação por novos usos e dinâmicas na área. Tendo em vista a escala e impacto de ambas as marcas num contexto global (grandes redes varejistas e nomes internacionalmente conhecidos), não parece provável que as mesmas funcionarão como "âncora" 
para novos comércios na área. No caso da Zibba, ser a única loja nesse trecho do Boulevard talvez se configure como uma vantagem no momento, mas não garante o sucesso do varejo.

Ainda que um ótimo projeto paisagístico tenha remodelado a região do Boulevard, favorecendo o caminhar e aumentando a sensação de segurança em geral, a ausência de "magnets" comerciais ou de usos permanentes nos armazéns e outros casarios do percurso torna o ambiente bastante deserto e pouco atraente. São poucas as pessoas que andam da Praça Mauá até o Aquário; ao contrário, preferem pegar 0 VLT e chegar diretamente ao destino. Os murais de grafitti e as reminiscências das intervenções artísticas em alguns dos casarões ainda fazem sucesso entre os turistas, que continuam os selfies na frente dos murais. Uma vez que os edifícios empresariais passarem a ter ocupação convidativa ao surgimento de novos comércios e serviços na região, não é difícil imaginar a abertura de uma grande marca gastronômica em parte de um dos armazéns ou casarões, ou uma rede de lojas varejistas conhecidas, por exemplo. Apesar da região manter-se "viva" durante o verão e a temporada de cruzeiros, com altos fluxos de passageiros, turistas e usuários em geral visitando os armazéns transformados em shopping centers e feiras gastronômicas, tão logo os navios desatracam e as pessoas se vão, o comércio se fecha e não resta nada para estimular o lazer - e o consumo - ao longo do percurso.

A questão da "segurança" também emperra em outros aspectos que não somente o bom desenho urbano. Fica claro que, apesar de, por um lado, a sensação de segurança ter aumentado pelo local renovado, melhor iluminação e o início da diversificação de usuários, por outro, os "olhos da rua" não se fazem ainda presentes na região do Boulevard, a não ser por alguns policiais militares e agentes civis da operação "Centro Presente". O desenho urbano da região, formado por ocupação perimetral, edifícios históricos, mescla de equipamentos culturais e espaços públicos renovados, instituições públicas e empresas privadas, ainda não é suficiente para promover a "segurança" em sua plenitude. Esbarrando em problemas de ordem social, como a alta desigualdade entre moradores de morros da região e funcionários dos órgãos públicos e corporações ou turistas, observa-se que há outras questões a serem discutidas em relação à segurança além do desenho urbano e do uso misto. Uma vez que o Boulevard consolide seus usos comerciais em edifícios até então desocupados e tenha novos empreendimentos residenciais de médio-alto padrão, a região adquirirá dinamismo maior e a ideia de "olhos na rua" talvez passe a funcionar de maneira mais eficiente do que agora.

Por enquanto, a "sustentabilidade urbana" do Boulevard, se dependente do setor terciário, ainda está comprometida, sendo observada com maior grau em áreas próximas ao centro consolidado (trecho mais próximo da Praça XV, por exemplo) e na Praça Mauá. Entretanto, mesmo nessas áreas, o papel do varejo ainda não está definido; a grande reunião de pessoas de diferentes grupos sociais é o único indício de um ambiente "sustentável". De modo geral, o Boulevard apresenta um caráter de tempo lento, próximo ao turismo contemplativo, servindo como grande promenade pela orla. Nos pontos nodais, como a Praça Mauá, adquire feições distintas, com maiores concentrações de pessoas e diferentes atividades ao mesmo tempo; mas, ainda assim, mantém seu caráter de lazer, alheio ao tempo rápido do trabalho e dos negócios existente em outras regiões do entorno. 


\section{Rua Sacadura Cabral: espaços tradicionais em transformação}

A Rua Sacadura Cabral, antes uma das frentes do Rio de Janeiro para o mar ${ }^{9}$, passou por inúmeras transformações físicas, sociais e econômicas ao longo dos anos até as recentes intervenções da OUC Porto Maravilha. Com aproximadamente $1300 \mathrm{~m}$ de extensão, conecta a Praça Mauá até 0 entroncamento das ruas Silvino Montenegro e Conselheiro Zacarias, onde se situa $05^{\circ}$ Batalhão da Polícia Militar, na Praça da Harmonia, passando por importantes edificações históricas e instituições, como o Hospital dos Servidores do Estado, o próprio edifício do batalhão, algumas partes do complexo do Moinho Fluminense, tombado pelo município, dentre uma série de casarões históricos, contabilizando juntamente ao entorno próximo dentro do Setor A da OUC 21 imóveis tombados e 27 imóveis preservados de acordo com o decreto que estabelece a APAC SAGAS (PORTO MARAVILHA, 201-?, p.226). Neste artigo, restringe-se a análise ao trecho entre a Praça Mauá e a Av. Barão de Tefé, parte da primeira fase da OUC.

A transformação da rua no "Distrito Criativo" do porto pauta-se na atração de empresas de Tecnologia da Informação e da indústria criativa (arte, arquitetura, design, moda e comunicação) para a área, inclusive através de incentivos fiscais. A iniciativa surgiu por empresas da região apoiadas pela CDURP e possuía em 2015 mais de 300 profissionais cadastrados. ${ }^{10}$ As empresas ocupam diversos casarões reformados, como a B2W (ver n.77, Figura 3), que presta serviços de TI para as Lojas Americanas, em três números ao lado de uma unidade das Lojas Americanas, e a Route Tecnologia, que desenvolve soluções de software para mobilidade urbana, segurança, logística, infraestrutura e aplicativos. Na esquina do Largo São Francisco da Prainha, um sobrado abriga a "Casa Porto" (ver n.37, Figura 3), centro cultural e incubadora de negócios para a região portuária, também oferecendo espaços de co-working para empresas da indústria criativa. ${ }^{11}$

Contando com duas grandes torres comerciais antigas e outros edifícios menores repletos de escritórios dos mais diferentes setores, uma grande escola municipal e diversos restaurantes ${ }^{12}$, bares e casas noturnas próximos a conhecidos pontos culturais e turísticos da região como a Pedra do Sal, a R. Sacadura Cabral possui fluxos intensos - e distintos - durante o dia (trabalho/estudos) e, em determinados dias da semana, também à noite (lazer). A atração de novas empresas à área poderá diversificar o perfil de ocupação, mesclando segmentos e perfil dos trabalhadores e, portanto, de consumo. Assim, a transformação do local em "distrito criativo" proporcionará uma nova identidade em termos de usos, produtos ofertados e tipologias de comércio e serviços (à nova função correspondem novas formas). Isso fica evidente quando se observa, por exemplo, alguns estabelecimentos recentes da rua, como a cafeteria ASA (Ação Sustentável da Amazônia) Açaí e a unidade reformada do Angu do Gomes, na esquina do Largo da Prainha.

No caso desse último, depara-se com uma situação de "lugarização" além da "localização". O "Angu do Gomes", que surgiu em 1955 com a venda de angu em barraquinhas no centro da cidade, em especial na Praça XV, aos poucos foi crescendo e abriu uma sede no Largo da Prainha em 1977, passando por diferentes endereços no local até seu fechamento, em 1986. Em 2008, Rigo Duarte, neto de um dos fundadores do restaurante, em sociedade com Marcelo Klang, reabriu a casa no número 17, que funcionou

\footnotetext{
${ }^{9}$ É por este motivo que existiam na rua diversos trapiches e algumas docas, como as Docas do Imperador, edifício imponente na Avenida Barão de Tefé hoje ocupado pela ONG Ação da Cidadania. Um desses trapiches foi transformado em bar/boate, 0 chamado "Trapiche da Gamboa", próximo ao Cais do Valongo, muito frequentado por suas noites de samba.

10 Ver notícia relacionada: "Criativos e Coletivos". Portal Porto Maravilha, 12/08/2015. Disponível em: http://www.portomaravilha.com.br/noticiasdetalhe/4315 Acesso em: 12/06/2017

11 Ver notícia relacionada: "Mais Espaço para Criatividade". Portal Porto Maravilha, 03/07/2015. Disponível em: http://portomaravilha.com.br/noticiasdetalhe/3677. Acesso em: 12/06/2017

12 Representam, com bares e lanchonetes, mais de $21 \%$ dos estabelecimentos desse trecho da rua.
} 


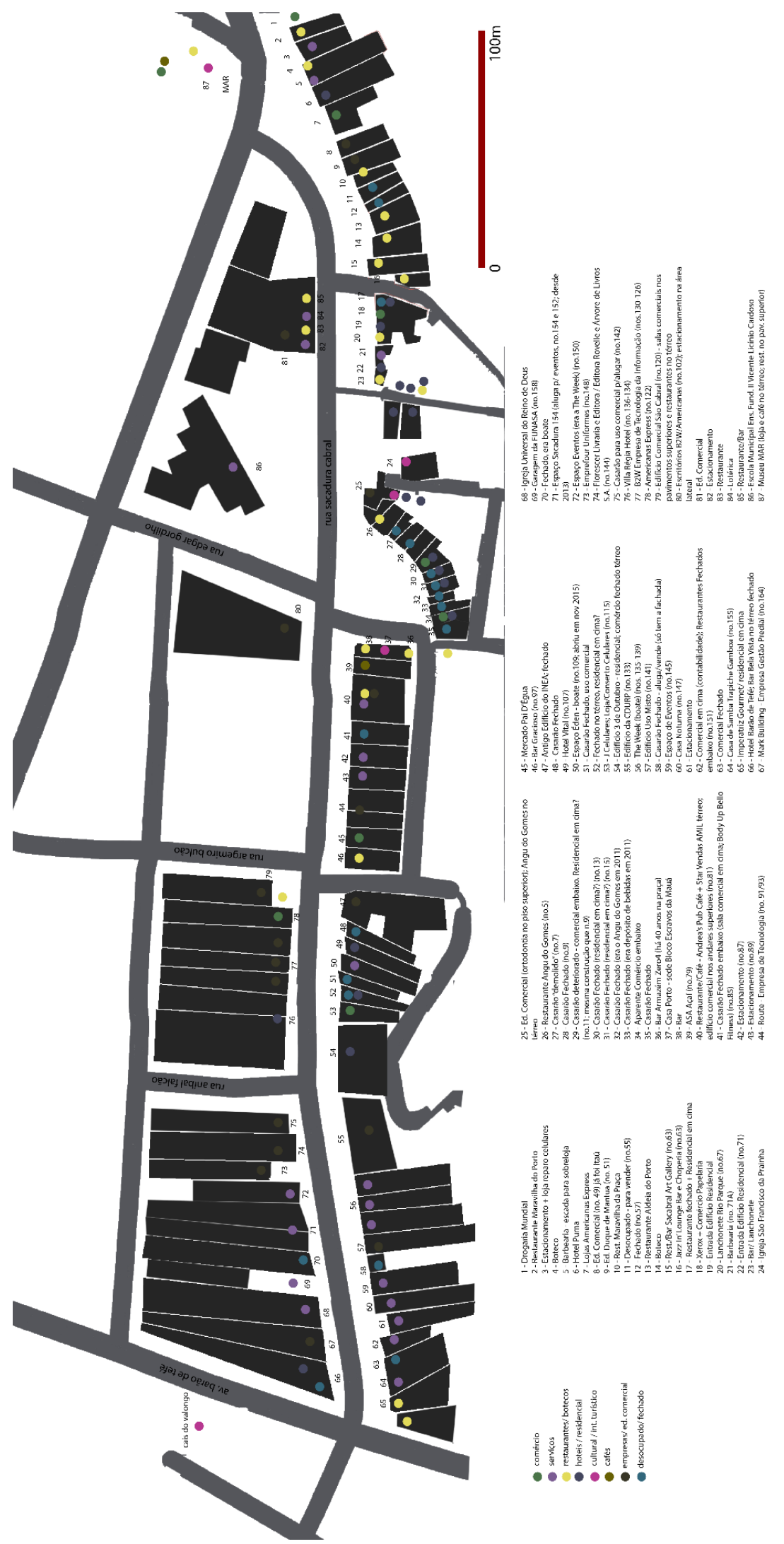

Figura 3. Mapa de uso do solo elaborado em maio de 2017 na R. Sacadura Cabral, no trecho parte da $1^{\text {a }}$ fase da OUC Porto Maravilha. (Renata Sanchez, 2017) 
até 2013, quando o restaurante se mudou para um casarão maior e de maior visibilidade, na esquina do Largo (Figura 5). Segundo Duarte, manter o estabelecimento na região em que tudo havia começado era fator importante para se preservar a tradição do negócio e, consequentemente, a identidade e imagem do mesmo. ${ }^{13} \mathrm{O}$ público-alvo é formado por trabalhadores da região, que vão ao restaurante principalmente para o almoço (um dos mais concorridos), mas também para o happy hour. A posição privilegiada da casa em frente à praça permite que mesas e cadeiras sejam postas no lado de fora sem perturbar os fluxos de pedestres da rua, possível graças às reformas da OUC no Largo.
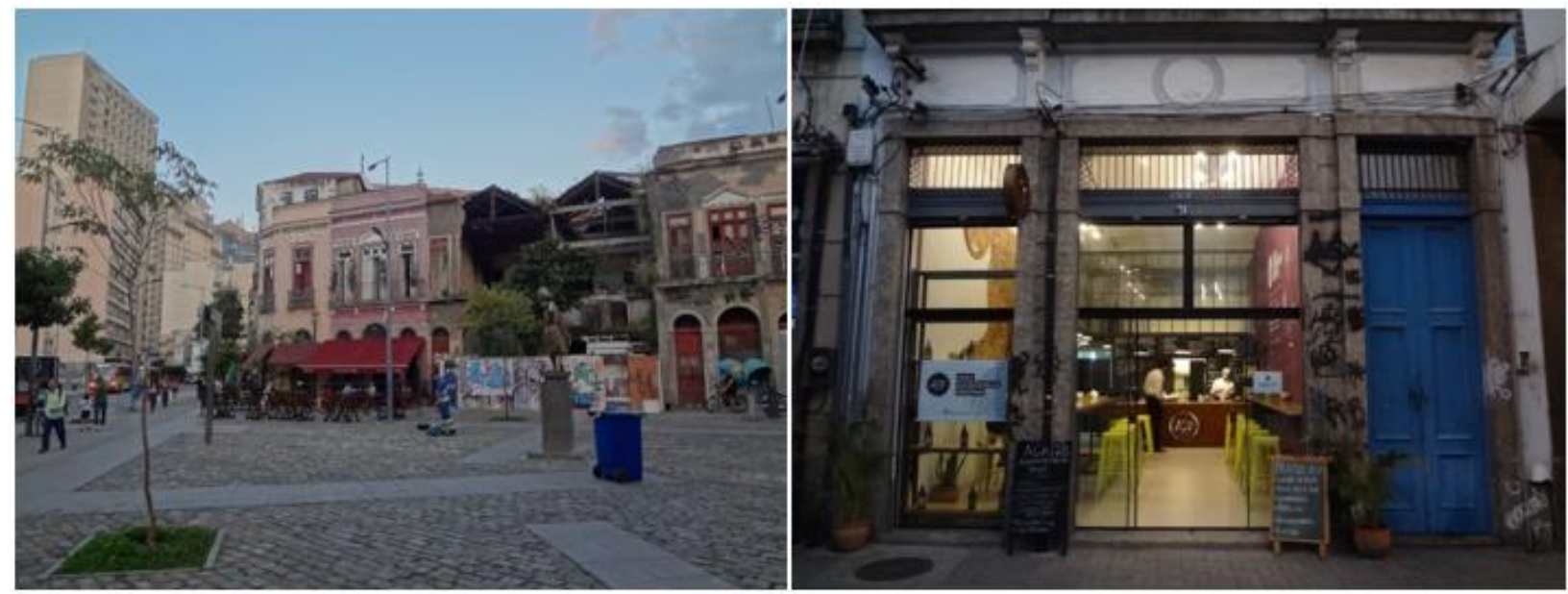

Figura 4. À esquerda, o atual Angu do Gomes, na esquina do Largo da Prainha reformado, que atrai boa parte dos trabalhadores de escritórios na região. À direita, fachada do novo café inaugurado para as Olimpíadas na Rua Sacadura Cabral, ASA Açaí, com design descolado para um novo público ainda a se consolidar (Renata Sanchez, 10/05/2017)

Aberto para as Olimpíadas, o ASA Açaí (Figura 5) possui design "descolado" (comum em estabelecimentos em áreas mais nobres do Rio) e atrai consumidores por ser justamente o que nenhum outro estabelecimento da rua ainda é. Pertencente ao grupo "Aprazível", restaurante originário em Santa Teresa, é um comércio local carioca, porém não daquela região. Durante os Jogos, atraía bastantes estrangeiros, seja pelo produto apreciado por esses - 0 açaí -, seja pela arquitetura, mais próxima de um padrão "global", ainda que com toques brasileiros. Os preços também refletem um novo perfil de consumo procurado; são dos mais altos da região (um café por $\mathrm{R} \$ 6,50$, por exemplo). No entanto, produtos diferenciados e com ingredientes orgânicos parecem garantir que o preço ainda compense a "experiência". Próximo a algumas torres e edifícios comerciais, o público-alvo também é de trabalhadores da região, que frequentam a casa especialmente para almoço e cafés e após o trabalho, para pequenas compras para viagem. Turistas também são frequentes, porém o restaurante abre aos sábados em horário reduzido (das $12 \mathrm{~h}$ às $16 \mathrm{~h}$ ) e fecha aos domingos, dia de considerável fluxo na Praça Mauá. Apesar de próximo ao polo cultural formado pelos museus na referida praça, o entorno do restaurante permanece bastante vazio aos finais de semana, com vários estabelecimentos fechados (o público-alvo não está ali) e fluxo bem menor de pessoas na Rua Sacadura Cabral, algo que provavelmente explica os horários reduzidos de funcionamento, mas também impacta na formação de ambientes mais vivos em outros períodos e dias da semana.

\footnotetext{
${ }^{13}$ Rigo Duarte, sobre o primeiro estabelecimento que inaugurou, no número 17: “(...) [o angu]continua como carro chefe da casa. Além disso, ainda estamos na Região Portuária, na mesma rua em que o meu avô começou. Isso é muito legal, dá uma identidade.(...)Mas conquistamos novos clientes, um público nosso. Para isso, precisávamos de uma cara nova para o angu. 0 resultado se vê hoje, vindo aqui. As pessoas gostam, o ambiente é agradável. É novo e tradicional ao mesmo tempo". (LOPES, 2017)
} 
A questão dos fluxos na rua tem ligação direta ao funcionamento do comércio. Nesse sentido, as referidas mudanças urbanas realizadas pela OUC também impactam no comércio da região. Um caso emblemático observado pessoalmente refere-se à retirada de vagas de estacionamento à frente do comércio da rua no trecho mais próximo da Praça Mauá, em virtude do alargamento da calçada, fazendo com que alguns clientes mais destemidos parem o carro de maneira irregular. Para a Drogaria Mundial, ali há mais de 25 anos, tal mudança foi prejudicial para as vendas, segundo um dos funcionários mais antigos. Além disso, 0 reposicionamento de pontos de ônibus e alteração do percurso de algumas linhas mudaram a dinâmica de fluxos na rua, impactando nas compras por conveniência daqueles que embarcavam ou desembarcavam próximo à farmácia. Segundo o mesmo funcionário, a retirada da rodoviária fluminense da Praça Mauá (0 Terminal Mariano Procópio, inaugurado em 1950, que fechou em 2011 para as obras do Museu MAR) diminuiu drasticamente 0 número de consumidores da drogaria e de outros comércios da região. ${ }^{14}$ Atualmente, transformada em polo turístico e cultural, a Praça Mauá atrai outro perfil de usuários, exigindo adaptação do comércio da região, se quiser se manter dinâmico e sustentável, isto é, "resiliente", como descrito por Salgueiro (2011).

Com a mudança do perfil do local (ou sua expectativa, pelo menos), o preço de imóveis já subiu. $15 \mathrm{Um}$ dos bares analisados, o Gracioso, teve aumento em seu aluguel de mais de 300\% desde o início das obras da OUC, em 2011. O dono admite que tem sido difícil levar o negócio, uma vez que a conta não fecha, mas não deseja demitir os funcionários, que trabalham há décadas com ele. Funcionando desde 1957 sob o mesmo nome, o bar sempre foi gerido por um mesmo grupo de amigos e familiares e fez tradição no bairro da Gambôa. Antes dele, havia outro bar no mesmo local, o que consolida a imagem do ponto comercial. Uma das críticas que o dono colocou em relação ao projeto da renovação da área refere-se à diminuição das vagas de estacionamento na rua e à pouca funcionalidade do VLT às pessoas que trabalham/moram na área (turistas são os mais beneficiados pela obra). 0 maior movimento é durante a semana no almoço e nas noites de samba da Pedra do Sal (segundas e sextas), quando o bar fica lotado.

A especulação com imóveis parece não atingir todos da mesma forma; alguns imóveis da rua são de propriedade do Hospital da Ordem Terceira da Penitência, de forma que os alugueis não sejam tão regulados pela lógica de oferta e demanda do mercado. Um desses casos é o imóvel onde funciona uma barbearia (n.21 na Figura 7), em uma das lojas térreas de um edifício residencial. Ali desde 1938 (atual gestão desde 1992), a barbearia fez tradição e atrai público cativo de trabalhadores dos inúmeros escritórios da região, não dependendo de fluxos de passagem estimulados por transporte público, como no caso da drogaria mencionada. Assim, as obras da OUC pouco influenciaram no movimento do negócio; aqui, a localização do comércio interfere menos para seu sucesso que a qualidade do serviço e a tradição/continuidade do mesmo.

\footnotetext{
${ }^{14}$ Segundo dados da CODERTE (Companhia de Desenvolvimento Rodoviário e Terminais do Estado do Rio de Janeiro), cerca de oito milhões de passageiros eram atendidos diariamente no Terminal, por cerca de mil ônibus que conectavam o Rio a outras cidades na região metropolitana. (O Globo. "Prefeitura passa a administrar terminal rodoviário na Praça Mauá, que vai abrigar escola de artes e pinacoteca." 01/04/2011. Disponivel em: https://oglobo.globo.com/rio/prefeitura-passa-administrar-terminal-rodoviario-na-praca-maua-que-vai-abrigar-escola-de-artespinacoteca-2802446. Acesso em: 12/06/2017)

${ }_{15}$ No site VivaReal, o imóvel comercial situado no número 142, um belíssimo casarão de quase três mil metros quadrados, pode ser alugado por $\mathrm{R} \$ 120.000,00$ por mês. A vantagem está no IPTU, de $\mathrm{R} \$ 100,00$. Ver: https://www.vivareal.com.br/imovel/imovelcomercial-saude-zona-central-rio-de-janeiro-2293m2-aluguel-RS120000-id-

75415265/? vt=sc:2\&utm_referrer=https\%3A\%2F\%2Fwww.google.com.br\%2F Acesso em: 12/06/2017. Segundo o mesmo site, o preço médio por metro quadrado do Centro do Rio de Janeiro figura em torno de $R \$ 8.676,00$, valor que se aproxima dos $\mathrm{R} \$ 9.600,00$ observados na Barra da Tijuca, por exemplo, outra área definida como centralidade pelas Olimpíadas do Rio, cujos imóveis, no entanto, são muito mais recentes e, por vezes, luxuosos.
} 


\section{CONEXÕES ENTRE O CENTRO CONSOLIDADO E O BOULEVARD OLÍMPICO: RUA DA ASSEMBLEIA E RUA DO MERCADO}

Tendo sido discutidos alguns dos pontos relacionados ao setor terciário que configuram os espaços e ambiências das localidades escolhidas, cabe ressaltar convergências e divergências com outras áreas consolidadas do centro da cidade. Em termos de desenho urbano, praticamente toda a área central é provida da mesma malha viária e tipologia, isto é, ruas predominantemente estreitas do período colonial com casarões antigos dos séculos $\mathrm{XIX}$ e início do século XX, cortadas por algumas avenidas mais proeminentes criadas pelas reformas higienistas do início do século XX, como a Avenida Rio Branco, onde se situam edifícios mais altos de estilo eclético e torres modernistas. Essa mistura de estilos e uma ocupação com poucos recuos frontais e laterais promovem uma característica interessante em termos de configuração urbana, que contribuem para a formação de uma localidade vibrante e dinâmica, apesar dos usos menos nobres, pouco ou nenhum uso residencial em determinadas regiões e vários estabelecimentos fechados aos finais de semana (especialmente aos domingos). A questão passa a ser, então, a diferenciação de usos e atividades que ocorrem em certas ruas ou entornos.

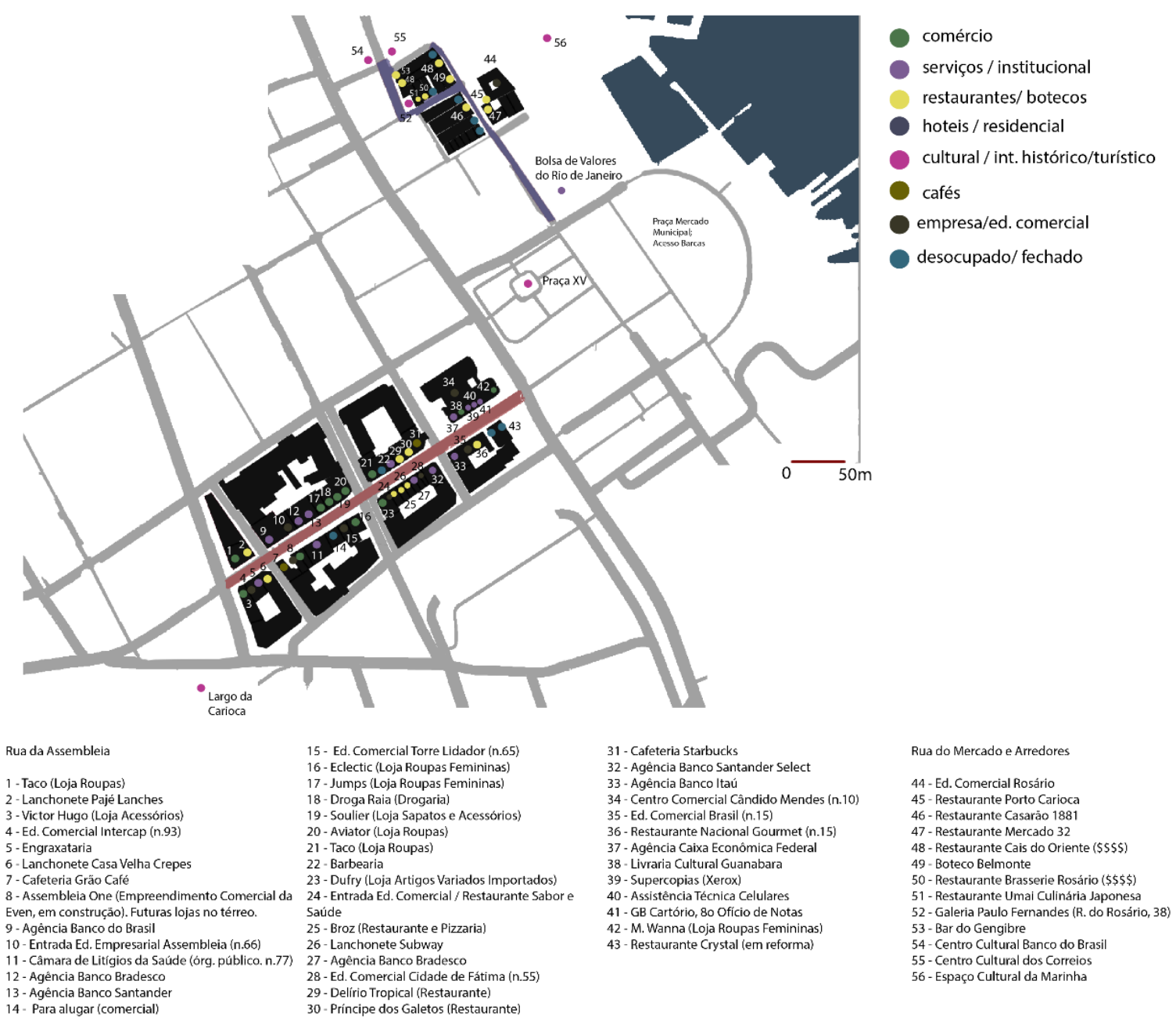

Figura 5. Mapa de uso do solo da Rua Assembleia e da Rua do Mercado, evidenciando grande número de comércios e restaurantes na primeira, e usos culturais e restaurantes na segunda. (Renata Sanchez, maio 2017) 
A Rua da Assembleia, por exemplo, é um importante eixo do centro de negócios, ligando o Largo da Carioca (ponto nodal e estação de metrô) à Praça XV, agora na orla renovada (Figura 4). Cruzada pela Avenida Rio Branco, possui localização privilegiada em termos de suas conexões, acessibilidade e carga histórica. Com dezenas de edifícios comerciais com lojas no térreo, a rua apresenta fluxos constantes, principalmente de pedestres - trabalhadores da área e ambulantes, em sua maioria. Além disso, alguns pontos de ônibus executivos ("frescões") na rua geram fluxos também para o entorno próximo. Típica de uma área com espaço terciário já consolidado, coexistindo usos empresariais e comerciais de alto padrão e outros de nível popular, a rua possui diversas marcas varejistas conhecidas no nível térreo, além de redes de restaurantes cariocas famosas também em outros bairros.

Um desses restaurantes é o "Delírio Tropical", primeira unidade da marca que surgiu em 1984, pela observação de um nicho ainda inexplorado na época para a alimentação: saladas elaboradas e sanduíches "caprichados", que visavam um público-alvo que trabalhava e se alimentava diariamente no centro da cidade. ${ }^{16} \mathrm{O}$ negócio cresceu e possui hoje dez lojas na cidade, em diferentes bairros. Outras redes conhecidas, inclusive internacionais, também possuem portas na Rua da Assembleia, como Subway e Starbucks. Essa última, inaugurada em 2015, possui localização privilegiada, em uma esquina com o edifício recuado, formando uma espécie de praça à frente do estabelecimento, bastante utilizada por fregueses para uma rápida reunião e conversa. A pequena praça é ponto também para alguns ambulantes, especialmente de pequenos lanches. Próximo à Avenida Rio Branco, a rua possui alguns comércios locais bastante antigos, como a lanchonete e padaria "Casa Velha", inaugurada há quase trinta anos no local e a "Engraxataria Cataldo", ao lado da lanchonete, que parece pertencer a outro "tempo". Da calçada, é possível ver fileiras de executivos tendo seus sapatos engraxados em poltronas do outro século. Inaugurada em 1949, a loja é uma das mais antigas da cidade e, segundo notícia de 2014 , recebia cerca de 200 pessoas por dia. ${ }^{17}$ Os números não parecem ter mudado muito; o estabelecimento estava cheio por volta das $13 \mathrm{~h} 30$ de uma quintafeira. Ali, pesa a tradição e a qualidade do serviço para a manutenção e resiliência do estabelecimento comercial, apesar de qualquer mudança no entorno. A clientela é cativa e predominante dos inúmeros escritórios da região. Mais que a localização favorável, pela proximidade ao público-alvo, a tradição do nome e ofício determinam a sustentabilidade do negócio; cria-se uma imagem e simbolismo em torno do ato de "engraxar", que supera a funcionalidade do próprio ato. Segundo a mesma notícia, os clientes preferiam ler revistas e jornais ao invés de acessar seus celulares, enquanto tinham seus sapatos engraxados. Observase um claro exemplo do "tempo lento" descrito por Cachinho, oposto ao intenso tempo rápido experimentado na rua.

Tempos distintos também podem ser observados na relação entre passantes e o comércio ambulante (como de bijuterias e roupas) ao longo de alguns trechos da Rua da Assembleia, atraindo olhos calmos e curiosos, e no edifício comercial localizado no fim da rua, próximo à Assembleia Legislativa do Rio de Janeiro, com um subsolo de lojas paralelo à via, acessado pela calçada, criando outro caráter urbano. Neste, a delimitação entre espaço público e semiprivado cria fluxos distintos, inibindo atividades espontâneas da rua no subsolo. Ali, uma agência da Caixa e um cartório de notas parecem ser as âncoras comerciais. Além dessa agência da Caixa, a Rua da Assembleia caracteriza-se por uma série de agências bancárias, algo inexistente no trecho estudado da Rua Sacadura Cabral e escasso no trecho do Boulevard Olímpico discutido anteriormente (havia apenas uma agência, da Caixa também, ao lado do casarão da San Chef). Percebese que a localização dessas agências (a maioria de bancos privados) se relaciona diretamente ao

\footnotetext{
${ }^{16}$ Ver: O Delírio. História. Disponível em: https://www.delirio.com.br/Home/Empresa historia

${ }^{17}$ BERTOLUCCI, Rodrigo. "Com fila na porta e média de 200 clientes por dia, engraxataria resiste no Centro há 65 anos". Jornal O Globo, 01/11/2014. Disponível em: https://oglobo.globo.com/rio/com-fila-na-porta-media-de-200-clientes-por-dia-engraxatariaresiste-no-centro-ha-65-anos-14099608 Acesso: 12/06/2017.
} 
contingente de empresas e funcionários que são clientes-potenciais na região e à centralidade de alto padrão observada, diferente do que ocorre na região portuária, com público-alvo ainda de nível socioeconômico inferior.

Toda dinâmica encontrada durante a semana nos horários comerciais acaba, no entanto, a partir das 19h, quando as lojas começam a fechar e os trabalhadores a irem embora. Poucos cafés e lojas ainda permanecem abertos, recebendo clientes após o trabalho. Em termos de sustentabilidade urbana pela variedade de atividades comerciais e grupos sociais presentes (ainda que separados entre vendedores $\mathrm{e}$ consumidores), a Rua da Assembleia parece preencher os requisitos; no entanto, fica claro que a região como um todo se beneficiaria se residências de médio-alto padrão existissem na área, impulsionando a abertura do comércio em outros horários e aos finais de semana, produzindo novas dinâmicas em mais períodos.

Essa crítica, que vale para grande parte da região central, pode ser observada também na Rua do Mercado, outra localidade escolhida para confrontar as análises feitas até então. Caracterizada por casarões do final do século XIX e início do século XX, abriga o edifício da Bolsa de Valores do Rio de Janeiro, construído em 1934 (LUCENA, 2016), que até hoje funciona como grande gerador de fluxos da área. Os poucos restaurantes que ocupam os centenários casarões na rua, de médio-alto padrão, possuem como públicoalvo os trabalhadores da instituição, havendo, por exemplo, uma unidade do Boteco Belmonte, badalado bar carioca com diversas casas na Zona Sul do Rio de Janeiro. A ambiência promovida pelos casarões sem recuo, com fachadas ricas em detalhes e uma rua praticamente para pedestres, favorece a permanência e o 'estar', criando uma esfera de tempo lento em meio ao centro, ainda que próxima a ruas movimentadas. Além disso, o contraste entre a forma de ocupação dos casarões perimetrais com o alto Edifício Rosário 1 (antes sede da Companhia de Navegação Lloyd Brasileiro, passou por retrofit em 2012 após ter ficado fechado por mais de quinze anos ${ }^{18}$ ) forma uma espécie de praça, beneficiada pela posição próxima à orla renovada e abertura aos pedestres.

Ao final da Rua do Mercado, tem-se um dos restaurantes mais refinados da região, o "Cais do Oriente", em um casarão eclético com apenas a fachada preservada. Premiado pelo Guia Michelin, o restaurante é frequentado por trabalhadores de alto nível da região, inclusive aos finais de semana. Pela localização "discreta", ou em ruas de pouco fluxo, a clientela é formada por aqueles que já conhecem a casa e os serviços ofertados. Caso similar é o da Brasserie do Rosário, na rua perpendicular, também ocupando um casarão reformado com ambiente e preços "requintados". Próximo a tais restaurantes, estão dois importantes centros culturais da cidade: 0 Centro Cultural Banco do Brasil (CCBB) e o Centro Cultural dos Correios, espaços em que também o tempo lento se manifesta e que ajudam a região a atrair diferentes usuários em horários e dias distintos da semana.

\section{CONCLUSÕES}

A partir das análises conduzidas, são depreendidos alguns pontos conclusivos sobre a relação entre o setor terciário, desenho urbano e sustentabilidade urbana dos locais estudados. Primeiramente, reitera-se a necessidade de polos geradores de fluxos para a sustentabilidade econômica do espaço terciário, principalmente através de residências, grandes empresas, órgãos públicos e instituições. A existência desses polos foi observada em todos os locais estudados, faltando, no entanto, usos residenciais na área

\footnotetext{
18 Ver "Rosário 1 Office Center: João Fortes Engenharia realiza retrofit no Centro do Rio". Disponível em: http://www.portalvgv.com.br/site/rosario-1-office-center-joao-fortes-engenharia-realiza-retrofit-no-centro-do-rio/
} 
da Rua Assembleia e Rua do Mercado e uma maior variedade nos mesmos na Rua Sacadura Cabral. Consequentemente, uma vez dadas as condições para o espaço terciário surgir, pode-se afirmar que este se "retroalimentará". Tecidos urbanos com quadras e lotes menores, que misturam edifícios antigos a novos - portanto mais dinâmicos -, viabilizam a criação de pequenos negócios locais (que poderão crescer futuramente) e novos formatos, como o mencionado Delírio Tropical na década de 1980, no centro do Rio. Tal movimento começa a se desenrolar na Rua Sacadura Cabral ainda com pouca expressividade, mas será impulsionado com maior dinamização do local (maior diversidade de público, usos e atividades), assim como no Boulevard.

Segundo, quanto à temida gentrificação, observa-se que esta ainda está em gestação nas áreas estudadas dentro da OUC, mais especulativa que concretizada; predominam ainda diversos estabelecimentos tradicionais da área e negócios locais, mesmo com o aumento dos valores imobiliários. Se, por um lado, a Rua da Assembleia parece apresentar maior sustentabilidade urbana atualmente pelo variado perfil de usuários, a longo prazo, a Rua Sacadura Cabral demonstra maior potencial para tal, especialmente por abranger alguns usos residenciais, além dos comerciais. Com a futura construção de edifícios residenciais no entorno, de padrão mais alto, a área terá mais fluxos permanentes, além de impulsionar novas e diversificadas atividades.

Outra conclusão importante refere-se à principal razão para a ausência de dinamismo no Boulevard: faltam usos permanentes ao longo do percurso. Os armazéns são utilizados, por enquanto, apenas para eventos temporários, o que não contribui para ancorar atividades naquele local. A presença de grafites e murais por si só não atrai público e fluxos suficientes para a abertura de atividades comerciais ligadas ao turismo e ao consumo ao longo do trajeto, o que seria imprescindível para a ideia de lugares vibrantes e sustentáveis, uma vez que o varejo é um dos pilares apontados por Salgueiro para sustentabilidade urbana. Cabe esperar a abertura e funcionamento dos edifícios novos comerciais projetados na área para avaliar como (uma vez que essa demanda virá, com certeza) os fluxos demandarão novos negócios na área; ou seja, apenas em alguns meses aumentará o interesse imobiliário na área, se a situação econômica para investidores também melhorar. Apesar das âncoras culturais - o MAR, o Museu do Amanhã e o Aquário - e dos polos geradores de fluxos já existentes - as instituições governamentais ali presentes, por exemplo -, o Boulevard ainda permanece vazio e monótono, apesar de seu potencial surpreendente como centralidade de lazer e consumo. Motivos para tanto talvez sejam a regularidade nos horários em que os principais usuários frequentam a área - trabalhadores dessas instituições entram e saem no mesmo horário, fora do qual o local permanece vazio -, a uniformidade de usos (empresariais/corporativos, faltando residências ou escolas de ensino superior que geralmente atraem fluxos em diferentes horários) e a falta de atrações ao longo do trajeto, estando confinadas aos dois extremos do Boulevard.

Fica clara a enorme importância do desenho urbano no desenvolvimento da área; no entanto, evidencia-se também pela experiência nos locais estudados que o desenho urbano sozinho não é capaz de mudar 0 caráter de um lugar. Sua relação direta com a segurança, como exaltado por Jacobs e Gehl, encontra 0 entrave da gritante desigualdade social do Rio de Janeiro, o que faz com que lugares de bom desenho urbano encontrados na região central ainda apresentem sensação de insegurança por motivos outros que fogem à alçada da arquitetura e do urbanismo puramente. $O$ desenho urbano pode, entretanto, amenizar anúncios de segregação e exclusão, frequentemente associados às regenerações urbanas. Novos arranhacéus e ícones arquitetônicos surgidos pela alteração de gabaritos instituída pela OUC podem ser integrados ao tecido existente por um bom projeto envolvendo suas calçadas, fachadas e aberturas. A existência de edifícios históricos e espaços de tradição no imaginário cultural da cidade são benéficas ao desenvolvimento do bairro e, mescladas a novos empreendimentos e usos, especialmente novos usos residenciais de 
padrões diferentes, inclusive as altas torres, contribuirão para dinamizar e tornar o ambiente urbano extremamente vivo, como são muitos bairros que passaram por processos de renovação em outras cidades globais, como Brooklyn e Soho, em Nova lorque - infelizmente lembrados, geralmente, pelas mazelas da gentrificação ocasionada e não pela ambiência proporcionada.

Por fim, aponta-se a importância da reinvenção dos lugares para sua manutenção e sustentabilidade - sua resiliência. Impossível impedir que as cidades mudem, bem como sua sociedade e economia; tentar frear tal processo só causaria prejuízos à vida urbana. Garantir, no entanto, que aspectos da identidade local sejam preservados, para ancorar a memória da cidade, é fundamental em qualquer processo de intervenção - algo observado no trecho da Sacadura Cabral analisado através da preservação do patrimônio e nos comércios do século passado. 0 poder privado não deve ser encarado como um mal a ser combatido, mas sim um aliado à realização de interesses comuns: atender os desejos de governantes e empresários de uma cidade mais competitiva e dos habitantes de uma cidade mais humanizada. Nesse sentido, o desenho urbano pode exercer seu papel social, ao eliminar barreiras, abrir espaços públicos, congregar grupos sociais e proporcionar atividades diversas - inclusive as de consumo, para diferentes perfis.

\section{REFERÊNCIAS}

Arantes, O. (2002) Uma estratégia fatal: a cultura nas novas gestões urbanas. In: Arantes, O.; Vainer, C.; Maricato, E. A Cidade do Pensamento Único: Desmanchando Consensos. Petrópolis: Ed. Vozes.

BRASIL. Lei n 10.257 , de 10 de julho de 2001. Regulamenta os arts. 182 e 183 da Constituição Federal, estabelece diretrizes gerais da política urbana e dá outras providências. Disponível em: http://www.planalto.gov.br/ccivil 03/leis/LEIS_2001/L10257.htm Acesso em: 21/06/2017.

Burgess, R.; Carmona, M. (2009) The Shift from Master Planning to Strategic Planning. In: Planning through Projects: Moving from Master Planning to Strategic Planning - 30 Cities. Techne Press [pp.63-93]

Cachinho, H. (2010) Nos regimes do tempo no comércio da metrópole contemporânea. Anais do III CINCCI. São Paulo: FAUUSP.

Castells, M. (1983) The Process of Urban Social Change. In: Cuthbert, A. R. Designing Cities: Critical Readings in Urban Design. Blackwell, 2003.

Del Rio, V. (2001) Voltando às origens. A revitalização de áreas portuárias nos centros urbanos. Arquitextos, ano 02, n. 015.06, Vitruvius, São Paulo. Disponível em: http://www.vitruvius.com.br/revistas/read/arquitextos/02.015/859 Acesso em: 13/06/2017.

Dunn, K. M.; Mcguirk, P. M. Hallmark Events. (1999) [p 18-32]. In: Cashman, R.; Hughes, A. (eds.) Staging the Olympics: the event and its impact. Sydney: University of New South Wales Press.

Ferreira, J. S. W. (2004) O Mito da Cidade-Global: O Papel da Ideologia na Produção do Espaço Terciário em São Paulo. In: Pós - Revista do Programa de Pós-Graduação em Arquitetura e Urbanismo da FAUUSP/Universidade de São Paulo. Faculdade de Arquitetura e Urbanismo. N. 16, dezembro 2004. https://doi.org/10.11606/issn.2317-2762.v0i16p26-48

Gehl, J.; Gemzøe, L. (1996) PublicSpaces - Public Life Copenhagen 1996. ISBN 8774073052. Copenhagen: The Danish Architectural Press \& The Royal Danish Academy of Fine Arts School of Architecture Publishers, 3 a ed.

Gehl, J. (2013) Cidades para Pessoas. Tradução Anita Di Marco. 2ed. São Paulo: Perspectiva.

Gehl, J.; Svarre, B. (2013) How to Study Public Life. Tradução para o inglês de Karen Ann Steenhard. Washington: Island Press. https://doi.org/10.5822/978-1-61091-525-0

Lefebvre, H. (1970/1999). A Revolução Urbana. Belo Horizonte: Ed. UFMG. 
Lopes, Y. (2012) Angu de Cara Nova. Blog Porto Maravilha. 23/11/2012. Disponível em: https://blogportomaravilha.wordpress.com/2012/11/23/angu-de-cara-nova/ Acesso em 12/06/2017

Lucena, F. (2016) História da Rua do Mercado. Diário do Rio. 8/03/2016. Disponível em: http://diariodorio.com/histria-da-rua-do-mercado/

Nobre, E.; Bassani, J. (orgs.) (2015) Intervenções urbanas em áreas em transformação de cidades da América Latina. São Paulo: FAUUSP.

NTHC (National Trust for Historic Preservation). (2016) Preservation Green Lab. The Atlas of Reurbanism. Buildings and Blocks in American Cities. Washington, DC.

Porto Maravilha.[201-?] Operação Urbana Consorciada da Região do Porto do Rio. Estudo de Impacto de Vizinhança. V - Situação Atual e Futura. 5 - Uso e Ocupação do Solo. Disponível em: http://www.portomaravilha.com.br/conteudo/estudos/impacto-avizinhaca/V.\%20Situacao\%20Atual\%20e\%20Futura $\% 205 . \% 20$ Uso $\% 20 \mathrm{e} \% 20$ cupacao $\% 20 \mathrm{do} \% 20$ Solo.pdf Acesso em: 21/06/2017.

Rodrigues, R. (2016) Na San Chef, Na Área Portuária. 19/12/2016. Disponível em: https://www.viagemsemescalas.com/single-post/2016/12/19/Na-San-Chef-na-\%C3\%A1reaportu\%C3\%A1ria Acesso: 13/06/2017.

Salgueiro, T. B. (2011) The resilience of Urban Retail Areas. In: Salgueiro, T. B. \& Cachinho, H. Retail Planning for the resilient City. Consumption and urban regeneration. Lisboa: CEG.

Timothy, D. (2005) Shopping Tourism, Retailing and Leisure. Aspects of tourism. 23. Clevedon, Buffalo, Toronto: ChannelViewPublications.

Vargas, H. C. (2001) Localização do terciário num contexto de mudanças. In: Espaço terciário. O lugar a arquitetura e a imagem do comércio. São Paulo: SENAC.

Zerlang, M. (2005) The Cultural Turn in Contemporary Urban Planning. In: Cultural Planning: Report from Conference at Center for Urbanism. Copenhagen: The Royal Danish Academy of Fine Arts, School of Architecture.

\section{(9) $\odot \Theta \Theta$}

This title is licensed under a Creative Commons Attribution-NonCommercial-NoDerivs 3.0 Unported License. 